\title{
Relationship between Strategic Performance Management and Employee Retention in Commercial Banks in Kenya
}

\author{
George Mucai Mbugua ${ }^{1}$, Esther Wangithi Waiganjo ${ }^{1} \&$ Agnes Njeru $^{1}$ \\ ${ }^{1}$ College of Human Resource Development, Jomo Kenyatta University of Agriculture \& Technology, Nairobi, Kenya \\ Correspondence: George Mucai Mbugua, College of Human Resource Development, Jomo Kenyatta University of \\ Agriculture \& Technology, Nairobi, Kenya. E-mail: gemmucai@yahoo.com
}

Received: January 8, 2015

Accepted: January 15, 2015

Online Published: January 16, 2015

doi:10.5430/ijba.v6n1p53

URL: http://dx.doi.org/10.5430/ijba.v6n1p53

\begin{abstract}
The purpose of the study was to examine the relationship between strategic performance management practices and employee retention in commercial banks in Kenya. A survey design was used to gather the information needed to achieve the objectives. Qualitative and quantitative techniques were used. The study was carried out in commercial banks in Kenya which had operating Licenses from the Central bank of Kenya. Questionnaires were used to collect the data. The data was analyzed using descriptive statistics mainly percentages and frequency distribution. Correlation and regression analysis were used to test the relationship between the variables. The study established that organizations used strategic performance management through clear action value plan, target setting, setting of the realistic budgets, forecasting, performance measurements and review and finally compensation based on performance. The strategic performance management influenced the employee retention. The study recommended that the management of all commercial banks should employ more strategic performance management practices with the view of enhancing employee retention.
\end{abstract}

Keywords: employee retention, human resource management, strategic performance management

\section{Introduction}

Organizations are open systems operating in turbulent environment (Johnson \& Scholes, 2002). They can also be conceived of as complex networks of relationships between workers and managers of different grades within and between teams (Wright 2003). Globalization and its forces have also led to increased awareness and made customers to put pressure for better value products and services thus necessitating development of service quality strategies through the understanding of quality as perceived by the consumers of the services and products. The banking sector in Kenya is governed by the companies Act, the Banking Act, the central bank of Kenya act and the various guidelines issued by the central bank of Kenya (GOK). The central bank of Kenya which falls under the Ministry of finance docket is responsible for formulating and implementing monitoring policy and fostering the liquidity, solvency and proper functioning of the financial system. The banks have come together in Kenya under the Kenya bankers association which serves as a lobby for the banking sector interests. This forms a forum to address issues affecting the members (Central Bank report, 2008).

The commercial banks in Kenya have experienced increased competition for staff over the last few years resulting from increased innovations among the players and new entrants into the market (GOK). A circular from the central bank of Kenya highlights that due to the need for business continuity Management and to ensure that business operations are not adversely affected in the event of a major operational disruption, there is the minimum standards all supervised banking institutions must implement. Most banks in Kenya have embraced online community banking because of the developing interest in buying and selling goods online. Online banking such as Visa have given reason for the bank managers to rethink their strategies in taming the on line market. There has been a stiff competition in Kenyan banking industry in order to serve an informed generation. Most of the banks in Kenya have embraced their strategies in targeting Kenyans in the Diaspora because they are believed to send a lot of money to the banks in Kenya. The strengthening of the Kenyan economy for the last ten years due to the changes in governance has seen a major transformation in the banking industry. Commercial banks have been opened throughout the country to provide financial services. 
According to Wright (2004), (HRM) practices are key agents in building and maintaining trust and they permeate an organization and shape the employment relationships. Employees interpret human resource practices and the trustworthiness of management as indicative of the personalized organization's commitment to them. Perception of an organization's fairness and trustworthiness can be shaped through human resource policies and practices. Within each organization the choices of strategies and policies offer statements of intent and the nature of their implementation and delivery provides tangible evidence of the extent to which management's intentions are genuine and can be trusted (Skinner 2004). Implementation of the various (HR) policies and the consistency of their implementation are important as they provide tangible evidence of the fairness of the organization Armstrong (2002). According to Tzafrir (2005) trust in senior management is more likely to be based on the outcomes of organizational decisions and less on their interpersonal attributes meaning that it is not just the outcomes of organizational decisions that are important but also the way the said decisions are communicated.

Porter (2007) highlighted that a set of high performing human resource practices such as recruitment, training, job design, participation, teamwork, work life balance and rewards were noted as important aspects in attainment of Job fit and this in the long term implies that people experience better fit with the job and the organization when more extensive human resource practices are in place. Storey (2000) says that after organizational entry, in the training, performance appraisal, recognition and reward stages of the Human resource cycle, organizations continue to manage fit levels. Training and development practices are used not only for enhancing skills and knowledge needed to perform well in the job but also for strengthening the desired values. Ashleigh (2007) noted that the safety of the training environment is crucial for team members to learn about each other and develop trust. The supportive environment also fosters positive feelings about working with other team members.

According to Dimba (2010), management of performance within organizations' is widely accepted as being crucial in the achievement of various significant outcomes related to organizational success, including the productivity and quality of employees, their commitment and job satisfaction and consequently forms a key component of human resource management strategy and practice. Performance appraisal is a system that assesses the quality and quantity of an employees work. According to (CIPD, 2005) human resource strategies reflect the philosophy of senior management with regard to the treatment of human resources and address the various activities related to their management, meaning that the HR function supports corporate goals by developing and implementing people management practices which engage employees and encourage them to direct their efforts towards the achievement of organizational goals. Dimba (2010) gives that strategic human resource management practices that best predict high performance are training and development and compensation practices coupled with motivation. Luthans (2005) noted that the strategic human resource management practices for competitive advantage are: information sharing, job design, programmes, job analysis methods, participation programmes, incentive based compensation, benefits, training, grievance, selection and staffing and performance appraisal.

Stavrou (2005) found that the best human resource management practices are: training, share options, profit sharing, group bonus, merit pay, joint HR management bundle, communication( on strategy, finance, change work organization) career, and wider jobs. Ulrich (2005) identified the need for the HR professionals to move away from traditional HR specialisms and create a range of new roles which focus on business outcomes and organisational performance. He identified the need for Human Resource professional to become business and strategic partners who are crucially involved with senior managers and line managers in strategy execution and value delivery and driving change together with being an employee champion and a functional expert. The discussion of strategic human resource management and human resource strategies emphasizes the role of the human resource practitioner as a business partner (CIPD 2005).

\subsection{Statement of the Problem}

According to Abeysekera (2007), employee turnover is a major challenge for organizations but companies implementing effective human resource management practices can reduce the rate of employee turnover and increase in competitiveness due to the fact that by retaining staff an organization is able to keep its key asset. It is important to critically examine the actions of competitors as it directly or indirectly affects the organization. There are many ways an organization can retain its employees and gain sustained advantage over their competitors among them being the development of comprehensive human resource practices (Narsimha, 2000). According to Hausknecht (2009) there is so much literature information on employee turnover which gives the factors that cause employees to leave an organization but less is known on what compels employees to stay in an organization.

As a result of globalization the whole world have become single markets where companies have crossed their country of origin and opened their operations in other countries and this has created a challenge for organizations in 
terms of management of human resources (Tiwari 2012). Commercial banks in Kenya face many challenges in today's dynamic market place and in a global economy that has become increasingly competitive requiring development of products and services that can satisfy a more demanding customer base and building long term customer trust (Munyoki, 2010). According to Kiptugen (2003) in Kenya commercial Bank, proactive rather than reactive strategies form the basis of strategic planning. Mello (2005) highlights that successful organizations are increasingly realizing that of the number of factors contributing to performance and staff retention, Human resource is the most critical. Commercial banks in Kenya are in very stiff competition for customers and also for staff and these are coupled with the task of retaining the right talent (GOK).

According to Boxall (2003) the big question will which HR policies and practices are more likely to contribute to sustainable competitive advantage and in particular staff retention as organizations go through their life cycle. Purcell (2003) noted that there are two kinds of mature organisations that manage to survive industry development; the one that succeeds in dominating the direction of the industry change and the firm that manages to adopt to the direction of change. Various studies have been carried out on this area, for example Munyoki (2010) researched on the various human resource practices in Commercial banks in Kenya, Kiptugen (2003) carried a study on Human resource practices in commercial banks in Kenya a case study of Kenya commercial bank. Kamoche (2004) carried out a study on staff retention in public universities in Kenya. These studies covered the staff retention in Kenyan universities but did not cover the staff retention in commercial banks in Kenya. This study will investigate the link between the strategic employee recruitment practices and staff retention in Kenyan commercial banks.

\subsection{Hypothesis}

$\mathrm{H}_{\mathrm{O}}$ There is no significant relationship between strategic performance management and employee retention in commercial banks in Kenya.

\section{Literature Review}

\subsection{Theoretical Framework}

The study used the Hertzberg Two Factor Theory to explain the effect of strategic human resource management and employee retention. According to Samuel (2009) an employee who is not motivated is likely to leave the organization. This theory implied that a satisfied employee is motivated from within to work harde and to remain in the organization. It looks at two classes of factors associated with employee motivation; Satifiers and dissatisfiers. Armstrong (2010) gives the satisfiers as achievement, recognition, responsibility, advancement and growth. The disatisfiers are salary, relationship with supervisor, work conditions, status and security. According to Michael (2008), extrinsic factors such as good working environment, job security and intrinsic factors such as development and training have a major contribution to employee retention in organizations.

Hughes (2010) employees value both the internal and external factors in an organization to make a decision on whether to remain or leave the employment since they are doing so in exchange of their services to the organization. The above implies that both intrinsic and extrinsic factors influence the employee retention in an organization and so must always be put in to consideration as these factors are likely to influence retention. The theory fits into this study because there are factors both extrinsic and intrinsic which have been found to influence employee retention in the organization.

\subsection{Strategic Performance Management}

Performance appraisals are not uncommon to the banking industry. However, what counts as an appraisal or performance management varies a great deal in sophistication and organization. Here, the researcher seek to characterize 'performance management' as a type of Human Resource practice that can effectively help an organization to meet its retention objectives, in addition to other important business goals. As such, the researcher is referring to a process of employee performance evaluation that is closely tied to strategic objectives, that provides good feedback to employees and gives them a view of their longer-term progress within the company, and is potentially married to training and other development opportunities.

Performance appraisals inform a number of Human Resource decisions related to compensation, training, promotion, and even termination. However, as part of a human resources policy that values open communication and employee commitment, performance appraisals also allow objectives and values to be effectively communicated to employees and can ensure a steady stream of critical feedback about business processes (Dalton, \& Mesch, 1990). When closely aligned with ongoing training and career development, performance management can be a successful retention tool. According to Hom (1995) performance management aligns the goals of individual members to those of the organization with which they are associated. It requires clearly articulated and well-communicated strategic goals for the organization as a whole. 
As with other retention practices, employee perceptions about the performance appraisal system can have an important impact on their decision to stay with a company. Most importantly, effective performance management requires a system that is fair, and that employees trust as being fair, both in terms of procedure (for example, consistent and well-communicated evaluation criteria) and in terms of the potential benefits arising from such evaluations (for example, training, professional development). Indeed, fairness and openness about the evaluation process are of paramount importance when performance management is tied to specific rewards or advancement.

Price and Mueller (1981) developed a causal model for voluntary turnover. They proposed seven determinants that have an indirect impact on turnover through job satisfaction. Those determinants include: repetitive work, participating in job related decisions, being informed of job related issues, having close friends as co-workers, receiving good pay, being fairly compensated and having an opportunity to obtain a better job within the organization. Price and Mueller proposed that as job satisfaction increased, employee's showed a greater intent to stay with the organization.

Watson and Wyatt International found that HR practices and trust in management had the strongest impact on building commitment (Watson Wyatt, 1999). A study conducted from the social exchange theory perspective shows that organizations which exhibit a high level of commitment to their employees through HR practices, are rewarded with increased organizational effectiveness, employee involvement and commitment to the organization (Whitener, 2001). These high commitment HR practices include items such as selective staffing, developmental appraisal, competitive and equitable compensation, and comprehensive training and development activities (Whitener, 2001). Huselid (1995) found nearly one thousand firms, which invest in high performance HR management practices, including: comprehensive employee recruitment and selection procedures, incentive compensation and performance management systems, and extensive employee involvement and training. These practices were found to have both an economically and statistically significant impact on employee turnover and productivity (Huselid, 1995).

According to Willis (2000), direct compensation serves as the most critical issue when it comes to attracting and retaining talents. Parker and Wright (2000) also assert that there is an underlying assumption that money can influence behaviour hence a fair remuneration is understood to be the cornerstone of the contractual and implied agreement between employees and employers. As a result, some companies may even provide remuneration packages which are well above the market rate to attract and retain critical talents (Parker \& Wright, 2000). Most managers believe that money is the prime retention factor and many employees cite better pay or higher compensation as the reason for leaving one employer for another (Mathis \& Jackson, 2004). Khan (2010) argues that comprehensive compensation and rewards augmented by an effectual system of disbursement can play an effective role in attracting the best candidates, shaping employee behaviour and performance outcome, and facilitating retention of talents.

A number of studies have established that highly competitive wage systems promote employee commitment and thus result in the attraction and retention of a superior workforce (Becker \& Huselid, 1999; Shaw, Gupta \& Delery, 2005). Mathis and Jackson (2004) also argued that a balanced, fair and competitive compensation and reward system affect the retention of employees. This makes compensation and reward planning a vital dimension of effective HRM policies. Even though the reviewed literature have shown that the various performance management indicators like competitive wage, performance appraisal, training, the reward system among others have been found to influence employee retention in various organizations mainly in the developed countries, it would be interesting to find out the effect of strategic performance management in the commercial banks in Kenya.

\subsection{Employee Retention}

According to Abeysekera (2007), employee turnover is a major challenge for organizations but companies implementing effective human resource management practices can reduce the rate of employee turnover and increase in competitiveness due to the fact that by retaining staff an organization is able to keep its key asset. It is important to critically examine the actions of competitors as it directly or indirectly affects the organization. According to Kok (2003) there are sets of human resource practices which are influenced by the human resource profession and which are referred to as best practice and which if well implemented will ensure retention of staff. According to Chandler (2000), the main issue in human resource research is whether there is a set of policies and practice that represent a set of superior approach to managing people and which are associated with organizational performance and staff retention. There are various factors which affect human resource practices which include both internal and external factors and the same differs from one organization to another (Ozutku 2009). According to Narsimha (2000), there are many ways in which companies can gain a competitive edge or a lasting or sustained advantage over their competitors, among them the development of comprehensive human resource practices. 
To gain competitive advantage firms use different competitive strategies and these strategies are more productive when they are systematically linked with human resource management practices meaning that organizations can improve their environment by making efficient choices about human resource practices that consistently support the chosen strategy (Tiwari 2012). According to Capelli (2001), human resource practices enhance organizational performance and there is a clear link between human resource practices, workplace climate and employee retention. He found that those organizations which had implemented more progressive human resource practices and which reported a work place climate that strongly valued employee participation, empowerment and accountability tended to be better performing and hence competitive meaning employees will be happy continuing to work with them. With the high turnover in the commercial banks in Kenya, the study aimed at determining how the strategic performance management would influence employee retention.

\section{Methodology}

\subsection{Research Design}

This was a survey research design. A survey design was appropriate for this study because it allows collection of information for both independent and dependent variables using questionnaires (Orodho, 2003). This design allowed the researcher to combine both qualitative and quantitative research approaches. According to Kothari (2009) qualitative approaches provide verbal descriptions rather than numerical descriptions.

\subsection{Population}

The target population in this study was the forty four commercial banks in Kenya which had been given operational License by the Central bank of Kenya. The study population for this study was the heads of human resources in the individual commercial banks in Kenya. Due to manageability of the population, the researcher used census study in which all the elements participated in the study.

\subsection{Data Collection}

The research instrument was a questionnaire consisting of both open- ended and closed- ended type of questions. The closed ended questions were aimed at giving precise information hence minimizing bias. The open ended questions ensured that the respondents were given freedom to express themselves. The questionnaire in this study was divided into six sections with section one giving the identification of the respondent and the job title. The other sections had questions aimed at providing the information on the various areas of this study. Secondary data was collected through review of published literature such as the various bank publications, central bank of Kenya reports and publications and text books. The questionnaires were then delivered by the researcher with the help of the two research assistants to the respondents. The respondents were waited to fill the questionnaire and those who were not in a position to fill them were given a maximum of two weeks to fill them after which the questionnaires were collected.

\subsection{Data Processing and Analysis}

In this study data were analysed using Statistical package for social science (SPSS). All the questionnaires received were referenced and items in the questionnaire coded to make data entry easy. Descriptive statistics were estimated for the various variables. Frequency tables and graphs were made for all the variables. The data reliability was checked using the Cronbachs alpha index. Inferential data analysis was done using Pearson correlation coefficient, regression analysis (enter method) and multiple regression analysis (step wise method). The correlation was used to determine the direction of the relationship between the dependent and the independent variables. Multiple regression analysis was used to establish the relationship between the various strategic human resource practices and employee retention. Hypothesis testing using p-value was done because it gave the strength of the decision. According to Mugenda and Mugenda (2003) a significance level of 0.05 is recommended as it represents that results are at $95 \%$ confidence level. The statistical models to be used for analysis was multiple regression (enter method).

$\mathrm{Y}=\beta_{0}+\beta_{1} \mathrm{X}_{1}+€$

Where $\mathrm{Y}$ is the dependent variable employee retention

$\mathrm{B}_{0}$ is the constant

$\mathrm{B}$ is the coefficient of $\mathrm{X}_{1}$

$\mathrm{X}_{1}$ is strategic performance management 


\section{Findings}

\subsection{Reliability Test}

The Cronbach's Alpha values for all the indicators before and after extraction with a factor loadings value of less than 0.4 is presented. Cronbach's Alpha results in the first column were computed using results of all the indicators and the Cronbach's Alpha results in the last column were computed after the reduction of indicators/factors with factor loadings of less than 0.4. The Table 3 presents that all the seven factors had Cronbach's alpha value of 0.967 and factor loading between 0.936 and 0.738 . This rule out elimination of the strategic performance management factors as none of the factors had a loading of less than 0.40 . The Cronbanch's alpha value remained 0.967 since all the factors were retained. The Cronbach's Alpha value of more than 0.7 implied that the gathered data was reliable and therefore could be used for generalization.

Table 1. Factor analysis and reliability of strategic performance management

\begin{tabular}{|c|c|c|c|}
\hline \multirow{8}{*}{$\begin{array}{r}\text { Cronbach's Alpha } \\
\text { before } \\
\quad .967\end{array}$} & Indicators & $\begin{array}{l}\text { Factors } \\
\text { loading }\end{array}$ & $\begin{array}{c}\text { Cronbach's Alpha } \\
\text { after }\end{array}$ \\
\hline & $\begin{array}{l}\text { The management carries out performance } \\
\text { review of its actual performance, targets and } \\
\text { forecast for timely and corrective action }\end{array}$ & .936 & .967 \\
\hline & $\begin{array}{l}\text { The organization practices regular forecasting } \\
\text { to evaluate whether it is still on track }\end{array}$ & .901 & \\
\hline & The organization sets realistic budgets & .881 & \\
\hline & $\begin{array}{l}\text { The organization gives incentive } \\
\text { compensation to its employees for motivation }\end{array}$ & .873 & \\
\hline & $\begin{array}{l}\text { The organization practices performance } \\
\text { measurement }\end{array}$ & .796 & \\
\hline & $\begin{array}{l}\text { The organization practices target setting for all } \\
\text { its employees. }\end{array}$ & .792 & \\
\hline & $\begin{array}{l}\text { The organization has a clear action value plan } \\
\text { used to measure the performance }\end{array}$ & .738 & \\
\hline
\end{tabular}

\subsection{Strategic Performance Management}

The respondents were asked to state the level of agreement with the statements regarding to strategic performance management. The findings in Table 2 show that majority of the respondents $(72.5 \%)$ indicated that indeed the organization had clear action value plan used to measure the performance. As to whether the organizations practiced target setting for their employees, the study findings revealed that $67.5 \%$ of the respondents agreed that indeed the organizations practiced target setting for their employees. The findings show that $10 \%$ strongly agreed with the statement. The findings imply that most organizations practiced target setting for their employees. The study sought to determine whether the organizations set realistic targets with their employees. The findings of the study show that $72.5 \%$ of the respondents agreed that the organizations set realistic targets. The study sought to establish whether the organizations practiced regular forecasting to evaluate whether they were still on track. The findings show that $72.5 \%$ of the respondents agreed that the organizations practiced regular forecasting to evaluate their performance. On the practice of performance measurement by the organizations, the results show that $72.5 \%$ of the respondents agreed that the organizations practiced performance measurement. The results therefore mean that the organizations practiced the performance measurement to a large extent. The study sought to determine whether the management carried out performance review of its actual performance, targets and forecast for timely and corrective action. The results show that $77.5 \%$ of the respondents agreed that the managements carried out performance review of their actual performance, targets and forecast for timely and corrective action. Respondents were asked to state whether the organizations the gives incentive compensation to its employees for motivation. The results show that $75.0 \%$ of the respondents agreed that the organizations gives incentive compensation to its employees for motivation. The findings mean that the organizations motivate their employees through incentive compensations. 
Table 2. Strategic performance management

\begin{tabular}{|c|c|c|c|c|c|c|}
\hline & $\begin{array}{l}\text { Strongly } \\
\text { Disagree }\end{array}$ & Disagree & $\begin{array}{l}\text { Neither } \\
\text { agree nor } \\
\text { disagree }\end{array}$ & Agree & $\begin{array}{l}\text { Strongly } \\
\text { agree }\end{array}$ & Total \\
\hline $\begin{array}{l}\text { The organization has a clear action } \\
\text { value plan used to measure the } \\
\text { performance }\end{array}$ & 0.0 & 7.5 & 15.0 & 72.5 & 5.0 & 100.0 \\
\hline $\begin{array}{l}\text { The organization practices target } \\
\text { setting for all its employees. }\end{array}$ & 5.0 & 5.0 & 12.5 & 67.5 & 10.0 & 100.0 \\
\hline The organization sets realistic budgets & 5.0 & 10.0 & 5.0 & 72.5 & 7.5 & 100.0 \\
\hline $\begin{array}{l}\text { The organization practices regular } \\
\text { forecasting to evaluate whether it is still } \\
\text { on track }\end{array}$ & 7.5 & 7.5 & 7.5 & 72.5 & 5.0 & 100.0 \\
\hline $\begin{array}{l}\text { The organization practices performance } \\
\text { measurement }\end{array}$ & 2.5 & 5.0 & 12.5 & 72.5 & 7.5 & 100.0 \\
\hline $\begin{array}{l}\text { The management carries out } \\
\text { performance review of its actual } \\
\text { performance, targets and forecast for } \\
\text { timely and corrective action }\end{array}$ & 0.0 & 12.5 & 7.5 & 77.5 & 2.5 & 100.0 \\
\hline $\begin{array}{l}\text { The organization gives incentive } \\
\text { compensation to its employees for } \\
\text { motivation }\end{array}$ & 5.0 & 10.0 & 5.0 & 75.0 & 5.0 & 100.0 \\
\hline
\end{tabular}

\subsection{Employee Retention}

The study sought to determine the employee retention in the organizations. The respondents were asked to state the rate of turnover in the organization was minimal. The results show that half of the respondents $(50 \%)$ agreed that the rate of turnover in their respective organizations were low. The findings show that $12.5 \%$ of the respondents strongly agreed with the statement. The study sought to determine whether the respondents had the intention of leaving the organizations. The findings of the study show that slightly more than half of the respondents $(55 \%)$ had no intention of leaving the organizations. The findings also show that $30 \%$ of the respondents neither agreed nor disagreed with the statement. As to whether their work gives satisfaction to the employees, the findings show that majority of the respondents $(77.5 \%)$ agreed that within the organizations their work gave them satisfaction. The study sought to find out how long the respondents intended to stay in the organization. The findings of the study show that $42.5 \%$ agree that they saw future for themselves within this company. The findings show that $40.0 \%$ remained neutral as to whether they were seeing their future in the organization. The results mean that only a section of the respondents see future for themselves in the organization. On whether they were willing to work for the organization for the next five years, the results show that majority of the respondents (77.5\%) agreed that they would be working for their organizations for the next five years. Respondents were asked to state whether if it were possible to start all over again, they would seek employment elsewhere. The findings show that half of the respondents $(50 \%)$ indicated that indeed given chance they would seek job elsewhere if they were to start all over again. The respondents were asked to state whether they would take up a job given an attractive offer. The findings show that majority of the respondents $(70 \%)$ agreed that they would take up the offer. The findings mean that the respondents would take up a better opportunity if they came across. The findings however show that $62.5 \%$ of the respondents agreed that the work they did was very important to them. The findings of the study that the employees would leave if they got better offer, agree with Mathis and Jackson (2004) and Khan (2010) who argued that most managers believe that money is the prime reason for leaving one employer for another. 
Table 3. Employee retention

\begin{tabular}{|c|c|c|c|c|c|c|}
\hline & $\begin{array}{l}\text { Strongly } \\
\text { Disagree }\end{array}$ & Disagree & $\begin{array}{l}\text { Neither } \\
\text { agree nor } \\
\text { disagree }\end{array}$ & Agree & $\begin{array}{l}\text { Strongly } \\
\text { agree }\end{array}$ & Total \\
\hline $\begin{array}{l}\text { The rate of turnover in the organization is } \\
\text { minimal }\end{array}$ & 0.0 & 15.0 & 22.5 & 50.0 & 12.5 & 100.0 \\
\hline Have no intention of leaving the organization & 2.5 & 12.5 & 30.0 & 47.5 & 7.5 & 100.0 \\
\hline $\begin{array}{l}\text { Within this company my work gives me } \\
\text { satisfaction. }\end{array}$ & 2.5 & 5.0 & 12.5 & 77.5 & 2.5 & 100.0 \\
\hline I see a future for myself within this company. & 5.0 & 12.5 & 40.0 & 42.5 & 0.0 & 100.0 \\
\hline $\begin{array}{l}\text { If it were up to me, I will definitely be } \\
\text { working for this company for the next five } \\
\text { years. }\end{array}$ & 2.5 & 5.0 & 12.5 & 77.5 & 2.5 & 100.0 \\
\hline $\begin{array}{l}\text { If I could start over again, I would choose to } \\
\text { work for another company. }\end{array}$ & 5.0 & 10.0 & 35.0 & 45.0 & 5.0 & 100.0 \\
\hline $\begin{array}{l}\text { If I received an attractive job offer from } \\
\text { another company, I would take the job. }\end{array}$ & 2.5 & 7.5 & 12.5 & 70.0 & 7.5 & 100.0 \\
\hline The work I'm doing is very important to me. & 2.5 & 7.5 & 22.5 & 62.5 & 5.0 & 100.0 \\
\hline I love working for this company. & 2.5 & 7.5 & 27.5 & 45.0 & 17.5 & 100.0 \\
\hline
\end{tabular}

\subsection{Whether Strategic Performance Management Influenced Employee Retention}

The study sought to determine the extent to which the strategic performance management influenced employee retention. The findings in Figure 4.1 show that that $32.5 \%$ of the respondents indicated that the strategic performance management influenced the employee retention to a large extent. The findings further show that $25 \%$ of the respondents indicated that it influenced to a very large extent. From the findings of the study, it was evident that most organizations practiced forecasting to evaluate their position in the business. The findings agree with the views of Grigore, Bagu and Rada (2011) that organizations do regular forecasting to predict whether they are on track or whether correction and/or predictive action are needed to solve current or predicted problems. The findings that the organizations performed performance reviews for the employee agreed that Grigore, Bagu and Rada (2011) views that organizations should periodically review actual performance targets and forecasts to ensure that timely preventive and corrective action are taken. The findings of the study that the organization used incentive compensation to motivate its employees as a strategy for employee retention support the views of Willis (2000) and Parker and Wright (2000) who noted that compensation serves as the most critical issue when it comes to attracting and retaining talents. The fact that the organizations practiced strategic performance management where the employees are given incentive compensation for motivation for the retention of the employees, the fact that the organizations practiced target setting, setting of the realistic budgets is also supported by Walker (2001) that the employee retention was influenced by compensation and appreciation of the work performed, the provision of the challenging work, the chances to be promoted and the learning and good communication among others.

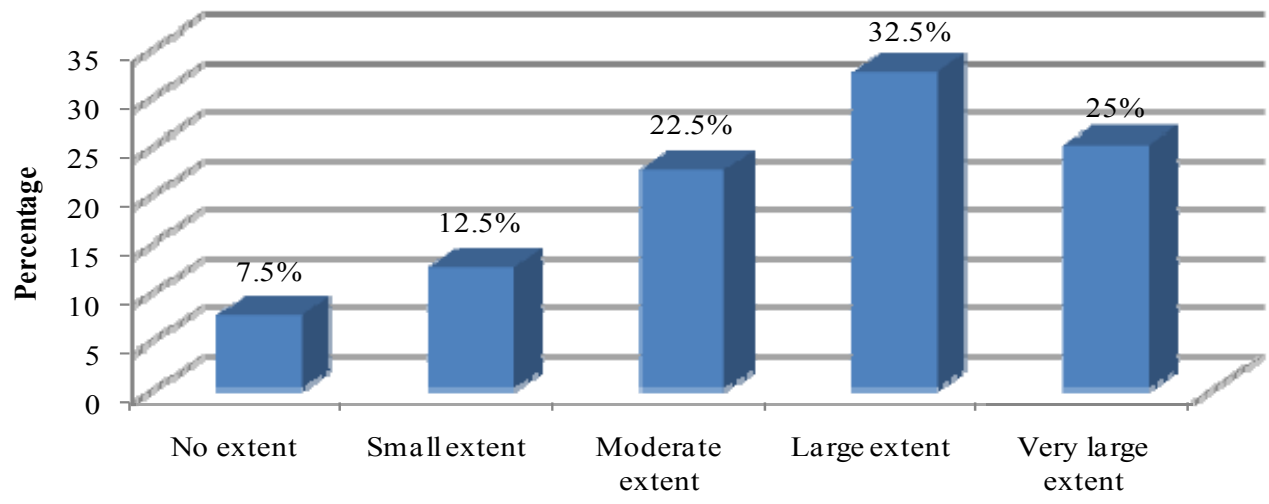

Figure 1. Whether strategic performance management influenced employee retention 


\subsection{Correlation Analysis}

The study conducted correlation analysis to test the strength of association/relationship between the research variables. The findings of the study in Table 4 show that there is a positive relationship between strategic performance management and employee retention with a Pearson's Correlation Coefficient of $r=445$ and at level of significance of 0.004 , was statistically significant as the p-value is less than 0.05 . The relationship can be described as not strong.

Table 4. Correlation analysis

\begin{tabular}{|c|c|c|c|}
\hline & & $\begin{array}{c}\text { Strategic performance } \\
\text { management }\end{array}$ & $\begin{array}{l}\text { Employee } \\
\text { retention }\end{array}$ \\
\hline & Pearson & 1 & .445 \\
\hline & Correlation & & \\
\hline & Sig. (2-tailed) & & 0.004 \\
\hline \multicolumn{4}{|l|}{ Strategic performance management } \\
\hline & Pearson & .445 & 1 \\
\hline & Correlation & & \\
\hline Domlor rotontion & Sig. (2-tailed) & 0.004 & \\
\hline
\end{tabular}

\subsection{Regression Analysis}

The researcher conducted a regression analysis to determine the significance relationship of strategic recruitment against the employee retention. The results in Table 5 show that the coefficient of determination $\left(\mathrm{R}^{2}\right)$ was 0.482 which means that $48.2 \%$ of the variance in employee retention in the organization is explained by strategic performance management. This though positive is a weak representation and therefore means there are equally other factors which determine employee retention in the organization.

Table 5. Model summary for strategic performance management

\begin{tabular}{ccccc}
\hline Model & $\mathrm{R}$ & R Square & Adjusted R Square & Std. Error of the Estimate \\
\hline 1 & $.694^{\mathrm{a}}$ & .482 & .468 & .660 \\
\hline
\end{tabular}

a. Predictors: (Constant), Strategic performance management

The analysis of variance shows that the significance of the $\mathrm{F}$ is 0.00 which is less than 0.05 . This implies that the regression model is statistically a significant predictor of the outcome variable.

Table 6. ANOVA

\begin{tabular}{|c|c|c|c|c|c|c|}
\hline \multicolumn{2}{|c|}{ Model } & Sum of Squares & $\mathrm{df}$ & Mean Square & \multirow{2}{*}{$\begin{array}{l}\mathrm{F} \\
35.305\end{array}$} & \multirow{2}{*}{$\begin{array}{l}\text { Sig. } \\
.000^{\mathrm{a}}\end{array}$} \\
\hline 1 & Regression & 15.364 & 1 & 15.364 & & \\
\hline & Residual & 16.536 & 38 & .435 & & \\
\hline & Total & 31.900 & 39 & & & \\
\hline
\end{tabular}

a. Predictors: (Constant), Strategic performance management

b. Dependent Variable: Employee retention

The beta coefficients of strategic performance management verses the employee retention results in Table 7 showed that there was significant relationship between the strategic performance management and the employee retention was positive since the coefficient of strategic performance management is 0.591 which is significantly greater than zero. The $\mathrm{t}$ statistics (1.679) was also greater than zero. This demonstrated that the strategic performance management had a positive influence on the retention of employees in the organization. Since the significance value of 0.000 which is less than the p-value of 0.05 , the study rejects the null hypothesis that there is no significant relationship between strategic performance management and employee retention in commercial banks in Kenya. The null hypothesis that there is significant relationship between strategic performance management on employee retention in commercial banks in Kenya is therefore accepted. 
Table 7. Coefficients

\begin{tabular}{|c|c|c|c|c|c|c|}
\hline \multirow[b]{2}{*}{ Mod } & & \multicolumn{2}{|c|}{ Unstandardized Coefficients } & $\begin{array}{l}\text { Standardized } \\
\text { Coefficients }\end{array}$ & \multirow[b]{2}{*}{$\mathrm{t}$} & \multirow[b]{2}{*}{ Sig. } \\
\hline & & B & Std. Error & Beta & & \\
\hline \multirow[t]{2}{*}{1} & (Constant) & 1.382 & .363 & & 3.803 & .001 \\
\hline & $\begin{array}{l}\text { Strategic performance } \\
\text { management }\end{array}$ & .591 & .099 & .694 & 5.942 & .000 \\
\hline
\end{tabular}

a. Dependent Variable: Employee retention

\section{Conclusion}

Based on the findings of the study the study concluded that the organizations used strategic performance management through clear action value plan, target setting, setting of the realistic budgets, forecasting, performance measurements and review and finally compensation based of performance. The strategic performance management influenced the employee retention. The study therefore concluded that the strategic human resource management influenced the employee retention.

\section{Recommendations}

The study recommended that the management of commercial banks should employ more strategic performance management such as setting targets, performance measurements performance review and giving incentive to employees the with the view of enhancing employee retention.

\section{References}

Abeysekera, R. (2007). The impact of human resource practices on marketing executive turnover of leasing companies in Srilanka. Contemporary Management Research, 3(3), 233-252.

Armstrong. (2000). A handbook of human resource management. London: Kogan Page.

Ashleigh, M. (2007). Trust and technologies: implications for organizational work practices, Decision support systems. London: CIPD.

Boxall, P., \& Purcell, J. (2003). Strategy and Human Resource Management. London.

Chartered Institute of Personnel and Development. (2005). Recruitment, retention, and turnover: a survey of the UK and Ireland. London: CIPD.

Dimba, B. (2009). The effect of SHRM Practices on Performance of Manufacturing MNCS in Kenya. A Moderating role of employee Cultural orientations. Proceedings of the $10^{\text {th }}$ Annual Conference. IAABD.

Hughes, J. C. (2008). Talent Management; A Strategy for Improving Employee Recruitment,Retention and Management within Hospitality Organizations. Journal of Contemporary Hospitality Management Education.

Kiptugen, E.J. (2003). Strategic responses to a changing competitive environment. Degree of Master of Business Administration (MBA), Faculty of Commerce, University of Nairobi.

Luthans, K.W., \& Sommer, S.M. (2005). The impact of high performance work practices on industry issues outcomes. Journal of managerial issues, 17(3), 327-345.

Mello, J.A. (2005). Strategic human resource management $\left(2^{\text {nd }}\right.$ ed.). South - western college.

Munyoki, J. (2010). An investigation into the marketing strategies used by commercial banks in managing serve breakdown among SME customer. Some experiences in Kenya. Thesis of University of Nairobi.

Narsimhe. (2000). Knowledge management and business strategies. El-Sayed Abou - Zeid Canada.

Porter, M.E. (2008). On Competition, updated and expanded edition. Boston Harvard Business School Publishing.

Samuel, O., \& Chipunta, C. (2009). Employee retention and turnover; using motivational variables as a panacea. African Journal of Business Management, 3(8).

Stavrou, E. (2005). Human resource management as a competitive tool in Europe. Working paper 0414, Henley Management College.

Storey, J. K. (2000). The realities of human resources management. Milton Keynes: Open University Press.

Tzafrir, S. S., Harel, G. H., Yehuda, B., \& Dolan, S. L. (2004). The consequences of emerging HRM practices for employee' trust in their managers. Personnel Review, 33(6), 628-647.

Ulrich, D., \& Brockbank, W. (2005). The human resources value proposition. Boston: Harvard Business School Press.

Wright, P., Gardner, T., Moynihan, L., \& Allen, M. (2004). The relationship between HR practices and firm performance: examining casual order. Personal Psychology Journal, 58(2). 